\title{
KESENIAN KETHEK OGLENG SEBAGAI RESOLUSI KONFLIK ANTAR PERGURUAN PENCAK SILAT
}

\author{
Oleh:
}

Diaz Kusuma Atmaja ${ }^{1}$

\begin{abstract}
Abstrak
Wonogiri lekat dengan kesenian Kethek Ogleng sebagai aspek sosial budaya yang diunggulkan. Kesenian Kethek Ogleng ini diharapkan menjadi resolusi konflik antar perguruan pencak silat di Wonogiri. Seperti halnya konflik yang melibatkan oknum dari perguruan pencak silat Persaudaraan Setia Hati Terate dan Persaudaraan Setia Hati Tunas Muda Winongo di Kabupaten Wonogiri diharapkan melalui kesenian Kethek Ogleng menemukan penyelesaian diantara keduanya. Tujuan penelitian ini untuk mengetahui peran kesenian Kethek Ogleng sebagai resolusi konflik antar perguruan pencak silat. Permasalahan penelitian ini timbul akibat konflik antar oknum dari Perguruan Pencak Silat Persaudaraan Setia Hati Terate dan Persaudaraan Setia Hati Tunas Muda Winongo di Wonogiri. Metode penelitian yang digunakan yaitu metode kualitatif dengan pendekatan studi kasus. Sumber data yang digunakan adalah data primer dan sekunder. Teknik pengumpulan data yang digunakan yaitu wawancara, observasi, dan dokumentasi. Analisis data yang digunakan peneliti dari Creswell berupa 5 tahapan yaitu (1) mengorganisasikan data, (2) memoing, (3) pengodean, (4) penafsiran data, (5) penyajian data. Hasil penelitian ini, menjelaskan penyelesaian konflik bahwa adanya kesenian Kethek Ogleng dapat menjadi resolusi konflik antar perguruan pencak silat Persaudaraan Setia Hati Terate dan Persaudaraan Setia Hati Tunas Muda Winongo di Kabupaten Wonogiri. Pementasan kesenian Kethek Ogleng dapat dikolaborasikan dengan pencak silat. Demikian, gerak Tari Kethek Ogleng yang atraktif layaknya seperti binatang kera. Hal ini menemui kecocokan untuk di kolaborasikan dengan gerakan pencak silat, ketika alur gerakan tari Kethek Ogleng yang berkelahi dengan seorang pangeran saat menyelamatkan seorang putri. Terkait kesenian Kethek Ogleng sebagai faktor penting dalam penyelesaian konflik, kesenian Kethek Ogleng menjadi wadah menuangkan perasaan gerakan pencak silat.
\end{abstract}

Kata Kunci: Kesenian, Konflik, Pencak Silat

\footnotetext{
${ }^{1}$ Mahasiswa Pendidikan Sosiologi Antropologi, FKIP-Universitas Sebelas Maret Surakarta, email: lintangkusuma981@student.uns.ac.id
} 


\section{Pendahuluan}

Perkembangan ekonomi di Kabupaten Wonogiri mengenai pariwisata dan pertanian yang terus tumbuh. Pariwisata ungulan sebagian besar dari sektor alamnya yang menyuguhkan pegunungan karst dan pertanian seperti pinus, cengkeh, dan kopi. Pariwisata alam terlihat dominan di daerah pegunungan karst tersebut. Sisi lain Wonogiri memberikan daya tarik mengenai kesenian Kethek Ogleng yang terus berkembang melalui sanggar tari di Wonogiri. kesenian Kethek Ogleng juga menjadi unggulan dalam mendukung pariwisata di Wonogiri. Melalui sanggar tari yang terdata oleh Dinas Pendidikan dan Kebudayaan Wonogiri Tahun 2019 mencatat sanggar tari sejumlah 34 . Sanggar lainnya pun tercatat seperti sanggar seni musik rupa 1 , seni musik teater 203, seni musik modern 224, dan seni musik tradisional 202.

Secara etimologi, kesenian Kethek Ogleng terbagi menjadi dua kata yaitu Kethek dan Ogleng. Kata Kethek mengartikan binatang kera sedangkan Ogleng berarti sarum demung (sarum besar). Irama gamelan dalam kesenian Kethek Ogleng. Memberikan penjelasan kata Ogleng yang diambil dari suara gamelan sarum demung (sarum besar) yang seolah-olah berbunyi Ogleng Ogleng Ogleng... Irama berasal dari lagu gending gangsaran pancer/laras nem (6).

Kesenian Kethek Ogleng mulai berkembang sejak 1920-an berawal dari bagian utara Wonogiri di Desa Kerjo. Saat itu kesenian Kethek Ogleng menjadi kesenian untuk mbarang atau ngamen. Bersamaan dengan kesenian Tayub (mirip dengan Tari Jaipong dari Jawa Barat), kesenian Tayub juga hanya tontonan yang besifat untuk mencari mata pencaharian seperti mbarang. Secara historis kesenian - kesenian Kethek Ogleng dengan kesenian Tayub tercatat pernah satu pementasan pada kesenian ledhek mbarang. Istilah ledhek mbarang merupakan sebutan pementasan kesenian Tayub dan kesenian Kethek Ogleng di Wonogiri. Hal ini diperkuat Lembaga Kesenian Nasional (LKN) cabang Wonogiri, telah meresmikan Kethek Ogleng sebagai kesenian yang berdiri sendiri.

Tak sebesar nama kesenian Kethek 
Ogleng yang terlahir sebagai kesenian khas Wonogiri, Perguruan pencak silat di Wonogiri memperoleh eksistensinya dengan berjuang dalam meraih prestasi. Melalui berbagai ajang perlombaan pencak silat seperti Madrasah Ibtidaiyah Muhammadiyah (MIM) Danan, Giriwoyo Wonogiri yang mengikutsertakan anak didiknya dalam UNS Open VII Kejuaraan Pencak Silat Kategori SD/MI Tingkat Nasional Tahun 2018. Peserta lomba dari MIM Giriwoyo, Wonogiri tersebut dapat menyabet 4 medali emas dan 2 medali perak (jateng.kemenag.go.id 2/5/2018).

Kabupaten Wonogiri dalam mengembangkan pencak silat tidak hanya berhenti menjadi peserta lomba saja. Turnamen seperti Pencak Silat Raden Mas Said Wonogiri Cup I menjadi ajang kompetisi lokal. Turnamen yang dilaksanakan di GOR Giri Mandala, Wuryorejo, Kecamatan Wonogiri, Kabupaten Wonogiri yang diikuti 397 atlet dari 80 kontingen. Turnamen Raden Mas Said merupakan agenda resmi IPSI Kabupaten wonogiri, melalui pengamatan IPSI hasil kejuaraan ini untuk usia SMP/SMA akan dibimbing mengikuti kejuaraan tingkat nasional.

Prestasi pencak silat di Kabupaten Wonogiri yang kian berkembang, tidak sejalan dengan persoalan konflik perguruan pencak silat yang terjadi. Konflik antar perguruaan pencak silat di Kabupaten Wonogiri mengakibatkan keresahan dalam masyarakat. Keresahan yang diakibatkan konflik kedua perguruan pencak silat yaitu Persaudaraan Setia Hati Terate (PSHT) dan Persaudaraan Setia Hati Tunas Muda Winongo (PSHW), membuat pemerintah proaktif dalam menangani permasalahan ini. Dua perguruan pencak silat yang besar di Wonogiri mendapat himbauan dari pemerintah untuk menahan diri. Perhitungan pemerintah Wongiri yang proaktif, berusaha untuk mengatasi konflik antar perguruan pencak silat dengan membetuk paguyuban seluruh organisasi bela diri (regional.kompas.com 9/5/2019).

Demikian, dalam penelitian ini memberikan gambaran untuk mempertimbangkan, kesenian Kethek Ogleng sebagai resolusi konflik antar perguruan pencak silat di Wonogiri. Tak hanya pencak silat yang berupa seni 
beladiri untuk menumbangkan lawan, akan tetapi seni beladiri yang dapat menciptakan keindahan. Hal inilah kesenian Kethek Ogleng memberikan bahwa pementasan kesenian Kethek Ogleng dapat dikolaborasikan dengan gerakan pencak silat.

\section{Methodology/Experimental}

Penelitian ini menggunakan metode penelitian kualitatif dengan pendekatan studi kasus. Metode penelitian kualitatif yaitu jenis penelitian dengan menyadari realitas objektif yang bersifat laten (tersembunyi), ketika menghadapi penelitian dilapangan menggunakan metode jamak atau biasanya disebut triangulasi. Pembuktian penelitian yang dilakukan oleh peneliti seringkali disebut triangulasi (Agus Salim,2006: 35). Pendekatan studi kasus sendiri digunakan peneliti karena penelitian yang diteliti terdapat kesenian Kethek Ogleng sebagai bagian terunik di Kabupaten Wonogiri. Keunikan lain kesenian Kethek Ogleng dalam penelitian ini sebagai resolusi konflik antar perguruan pencak silat

Menganalisis data yang diolah dari hasil transkip wawancara dengan proses seperti mengorganisasikan data, memoing (catatan penting), pengodean (coding), menafsirkan data dan penyajian data (Creswell,2015: 250-263).

Pengertiannya sebagai berikut:

1. Mengorganisasikan Data

Memilah data dari teks transkrip wawancara dan dokumentasi foto maupun dokumen-dokumen terkait kesenian Kethek Ogleng dan kasus konflik antar perguruan pencak silat.

\section{Memoing}

Setelah memilah data peneliti memahami wawancara dengan membuat catatan kecil berupa gagasan-gagasan yang terdapat dalam transkip wawancara ditulis kembali dalam catatan penting.

\section{Pengodean (Coding)}

Pengodean yaitu memilah data sesuai kebutuhan penelitian seperti, infomasi menegnai kesenian Kethek Ogleng dan kasus konflik PSHT dan PSHW.

\section{Penafsiran Data}

Data penelitian pada tahap penafsiran data diolah dengan cara mengombinasikan teori dengan data hasil temuan. Penafsiran data dalam penelitian ini bertujuan untuk mengetahui keberadaan kesenian Kethek Ogleng 
sebagai resolusi konflik antar perguruan pencak silat di Wonogiri.

\section{Penyajian Data (Data Display)}

Hasil dari penelitian disajikan dalam bentuk tulisan untuk mempermudah dalam menjelaskan suatu penelitian, terutama dalam penyelesaian kasus konflik perguruan pencak silat melalui kesenian khas Wonogiri.

\section{Hasil dan Pembahasan}

Kabupaten Wonogiri memberikan daya tarik mengenai kesenian Kethek Ogleng sebagai kesenian khas Wonogiri. Cerita rakyat tentang Kethek Ogleng berkembang di Wonogiri, bermula antara kerajaan Jenggala dan Kediri yang mempunyai hubungan dekat. Kedekatan kedua kerajaan diikat pernikahan seorang pangeran dari Jenggala dan putri Kediri. Pangeran Jenggala dikenal dengan nama Panji Asmarabangun menikah degan putri Kediri bernama Dewi Sekartaji. Pada suatu ketika mendapat amanah dari ayahnya untuk menjadi raja di Jenggala, akan tetapi Panji Asmarabangun merasa belum siap menggantikan ayahnya tersebut. Mental Panji Asmarabangun yang belum sanggup membuatnya melarikan diri dari kerajaan Jenggala.

Cerita rakyat Kethek Ogleng kemudian melatar belakangi alur tariannya. Pada dasarnya gerakan tari Kethek Ogleng memiliki hubungan karakter tokoh pewayangan Anoman si Kera Putih. Tokoh Anoman berkaitan erat dengan berkembangnya cerita rakyat Kethek Ogleng, diceritakan pada saat Panji Asmarabangun yang meninggalkan kerajaan Jenggala membuat suasana hati istrinya Dewi Sekartaji khawatir akan kepergian suaminya tersebut. Dewi Sekartaji memilih untuk mencari suaminya pergi kehutan. Kejadian ini terdengar oleh Panji Gunungsari, kemudian dia menyusul untuk mencari kakaknya tersebut. Panji Gunungsari dalam pencarian kakaknya dia menyamar menyerupai seekor kera. Dari sinilah alur pementasan tari Kethek Ogleng yang menampilkan sosok kera yang mencari kakaknya.

Kesenian Kethek Ogleng di harapkan dapat menjadi sarana pemerintah dalam menangani konflik yang ada di Wonogiri. Sebagaimana pemerintah mempunyai wewenang yang 
telah disahkan Undang-undang No.7 tahun 2012 mengenai penanganan konflik sosial, dijelaskan bahwa pemerintah berperan aktif untuk menyelesaikan segala bentuk konflik atau benturan fisik dan kekerasan lainnya yang dapat menghambat dan mengganggu stabilitas nasional serta pembangunan nasional.

Pencatatan Badan Pusat Statistik menyebutkan konflik massal dari tahun ketahun cenderung meningkat. Selama periode 2005 mengalami konflik massal terjadi di 1.655 desa/kelurahan. Pada tahun 2008 meningkat sebanyak 2.283 desa/kelurahan, peningkatan yang terjadi karena meningkatnya perkelahian di berbagai wilayah di Indonesia. Kajadian kejahatan tidak berhenti pada tahun 2008, tahun 2011 BPS mencatat terjadi perkelahian massal sebanyak 2.562 desa/kelurahan.

Data diatas konflik massal terjadi di daerah desa/kelurahan, fakta yang terjadi di Wonogiri konflik massal terjadi di pedesaan. Kasus yang terjadi di Wonogiri terlibatnya konflik antar perguruan pencak silat PSHT dan PSHW. Daerah wonogiri yang berupa pedesaan banyak tersebar wilayah perguruan pencak silat di setiap desa. Setiap desa di Wonogiri rata-rata terdapat pembangunan tugu organisasi bela diri. pembangunan tugu sering menjadi persoalan yang bersinggungan dengan organisasi perguruan pencak silat lain. Akibat persoalan pembangunan tugu yang dikira tidak tepat memicu konflik antar perguruan pencak silat tersebut (regional.kompas.com 9/5/2019).

Bukan tanpa alasan lain mengapa kesenian Kethek Ogleng menjadi resolusi konflik perguruan pencak silat di Wonogiri. Tari Kethek Ogleng memiliki alur cerita yang dapat dikolaborasikan dengan gerakan pencak silat. Alur cerita ini menjadi kunci untuk mengaplikasikan jurus pencak silat yang biasanya digunakan saling memukul satu sama lain. Hal ini perlu karena kasus yang sudah terjadi di Wonogiri mengenai konflik antar perguruan pencak silat sangat merugikan korban pertikaian tersebut.

Pementasan Kethek Ogleng terdapat 5 adegan dalam tariannya berikut penjelsannya; Pertama, adegan 
dimana Panji Asmarabangun yang meninggalkan kerajaan Jenggala. Kedua, adegan Panji Asmarabangun yang saling berbincang dengan Abdi Jarodeh dan Prasonta. Perbincangan berisikan ajakan Panji Asmarabangun terhadap Abdi Jarodeh dan Prasonta untuk meninggalkan kerajaan. Ketiga, adegan dua wanita yaitu Endang Lara Tompe dan mBok Randha Dadapan yang sedang berbincang. Kemudian datanglah Kethek Ogleng yang mengejar Endang Lara Tompe sebagai penyamaran Dewi Sekartaji. Keempat, adegan dari Panji Asmarabangun yang menyamar sebagai Jaka Asmara. Jaka Asmara berperan sebagai penolong Endang Lara Tompe yang dikira diganggu Oleh Kethek Ogleng. Endang Lara Tompe merupakan penyamaran dari Dewi Sekartaji. Kelima, Penutup diakhiri dengan terbukanya penyamaran para tokoh tersebut.

Resolusi konflik dalam menangani pertikaian antara perguruan pencak silat PSHT dan PSHW di Wonogiri, peneliti mengusahakan memberikan gambaran kolaborasi gerakan pencak silat dalam pementasan kesenian Kethek Ogleng. Gerakan tari kesenian Kethek Ogleng seperti halnya karakter Anoman si Kera Putih. Gerakan tari yang diadopsi dari binatang kera. Dimana penari mengusahakan gerakan tangan dan kaki layaknya seperti kera. Alur pementasan kesenian Kethek Ogleng menemui titik temu untuk mengolaborasi gerakan tari dengan pencak silat. Adegan ke 4 tari Kethek Ogleng terdapat adegan perkelahian si Kera dengan Jaka Asmara.

Adegan ke 4 ini dapat dikolaborasikan gerakan pencak silat, terutama saat penyelamatan Endang Lara Tompe. Penyelamatan seakan -akan terjadi benturan fisik antara Jaka Asmara dengan Kethek Ogleng. Gerakan pencak silat yang biasanya hanya digunakan untuk berkelahi akan lebih tersalurkan dengan kolaborasi seni tari. Alur yang dipentaskan Kethek Ogleng akan menjadi lebih bervariasi.

\section{Kesimpulan}

Berdasarkan pembahasan diatas, bahwa kesenian Kethek Ogleng dapat meredam konflik antar perguruan silat di Wonogiri. Dampak-dampak yang ditimbulkan dari adanya kesenian Kethek Ogleng, menghadirkan upayaa untuk 
meredam konflik dan mengitegrasikan perguruan pencak silat PSHT dan PSHW.

Disisi lain, kolaborasi yang ditimbulkan memperbaiki citra perguruan pencak silat memberikan pengaruh yang baik di masyarakat. Citra ini tentunya akan dinikmati masyarakat dalam bentuk lain. Semula yang dibicarakan tentang perguruan silat hanya konflik dan kekerasan menjadi lebih indah melalui kolaborasi seni.

\section{DAFTAR PUSTAKA}

Agus, Salim. (2006). Teori dan Paradigma Penelitian Sosial. Yogyakarta:

Tiarawacana

Badan Pusat Statistik. (2014). Kriminal 2014. Badan Pusat Statistik Jakarta.

Creswell, John W. (2015). Penelitian Kualitatif, Kuantitatif \& Desain Riset.

Yogyakarta: Pustaka Pelajar.

Pemenrintah Indonesia. (2012). Undang-Undang No.7 Tahun 2012 Tentang

Penanganan Konflik Sosial Dalam Tambahan Lembaran Negara Republik

Indonesia Nomor 5315. Jakarta: Sekretariat Negara.

\section{Website Surat Kabar Online:}

Wonogiri, Kemenag. (2018, 2 Mei). MIM Danan Wonogiri Sabet $4 \quad$ Medali Emas

Di UNS Open VIII Kejuaraan Pencak Silat Nasional.Jateng.kemenag.go.id.

Diperoleh 2 Nov 2019. https://jateng.kemenag.go.id/w

arta/berita/detail/mimdananw nogirisabet4medaliemasdiunso

penviiikejuaraanpencaksilatnas ional

Wonogiri, Kompas. (2019, 9 Mei). Bentrok 2 Perguruan Silat di Wonogiri Dipicu

Pembangunan Tugu.

Regional.kompas.com.Diperoleh 2 November 2019. https://regional.kompas.com/re ad/2019/05/09/21465731/bentr ok2perguruan- silat

diwonogiridipicupembangunan -tugu. 